\title{
Studi Kasus Asuhan Keperawatan Psikososial Pada Tn. P Dengan Masalah Ansietas Pada Penderita Abses Hati
}

\author{
Nama : Fince Indra Jaya Waruwu \\ finceindra13@gmail.com
}

\section{BAB I}

PENDAHULUAN

\subsection{Latar Belakang}

Masalah kesehatan fisik dan masalah kesehatan jiwa sering kali berjalan beriringan.pada saat individu mengalami kesehatan fisik, pada saat yang sama memungkin individu tersebut juga mengalami masalah kesehatan jiwa tetapi seiring kali tidak mendapatkan pelayanan asuhan keperawatan dengan baik. Asuhan keperawatan diera globalisasi ini harus didasarkan pada satu konsep yang meliputi aspek fisik, psikologis, sosiokultural dan spritual. Masalah kesehatan fisik menjadi ancaman kesehatan masyarakat terutama pada penyakit diabetes melitus. Dengan masalah kesehatan fisik pasien mengalami ansietas (Seaton,2018)

Kesehatan jiwa menurut Word Healt Organization (WHO) merupakan berbagai karekteristik yang mengambakan keselarasan dan keseimbangan kejiwaan yang mencerminkan kedewasaan kepribadianya.keperawatan jiwa memiliki sikap yang positif terhadap diri sendiri, tumbuh, kembang, memiliki persepsi sesuai kenyataan, dan kecakapan dalam beradaptasi dengan lingkungan (Pitter, 2021).Modrenisasi dan perkembangan teknologi membawa perubahan tentang cara berpikir dalam pola hidup masyarakat sehingga perubahan tersebut membawa pada konsekuensi dibidang kesehatan terutama keshatan jiwa berupa respon yang maldaptif. Stress merupakan gangguan kesehatan jiwa yang tidak dapat dihindari, karena merupakan bagian dari kehidupan.(Kumar, Rinwa, Kaur \& Machawal, 2020) 
Kecemasan pada penderita Stroke merupakan gangguan psikologis yang sering dialami pasien stroke fase akut yang disebabkan oleh gangguan serebral atau merupakan reaksi (Amila \& Sembiring, 2020). Terapi hipnotis lima jari merupakan proses kekuatan pikiran dengan mengarahkan tubuh untuk menyebukan diri memelihara kesehatan relekasasi melalui komunikasi dalam tubuh melibatkan indra visual, sentuhan, pedoman, penglihatan dan pendengaran (Pardede, Simanjuntak \& Waruwu, 2020).Kecemasan mampu mengakibatkan perubahan-perubahan fisiologis yang dapat menghalangi dilakukannya tindakan yang akan di berikan kepada seseorang. Terapi hipnotis lima jari memampukan pasien dalam mengontrol nyeri, stres fisiologis dan emosi (Pardede, Hulu, \& sirait, 2021).Berdasarkan uraian diatas maka penulis tertarik untuk mengambil kasus kecemasan pada Stroke dengan judul Asuhan Keperawatan Pada Tn. H Dengan Kecemasan Pada Penderita Stroke Di Bakti Luhur Kec. Medan Helvetia. Pertimbangan utama pengambilan kasus ini pada Tn. H karena pada kehidupan sehari-hari memiliki tekanan darah tinggi dan ekstramitas bawah pincang saat berjalan sehingga pada kondisilebih cepat mengalami cemas yang akan memperburuk kondisi.

Respon individu terhadap ansietas mempunyai rentang antara adaptif sampai maladaptif. Respon adaftif identik dengan reaksi yang bersifat destruktif. Reaksi yang bersifat kontruktif menunjukkan sikap optimis dan berusaha memahami terhadap perubahan perubahan yang terjadi baik perubahan fisik maupun efektif.(Stuart, 2018).

Ansietas yang dialami akan menentukan bagaimana mekanisme koping seseorang dalam mengatasi masalah tersebut baik mekanisme kpoing adaptif dan maladptif, individu yang memiliki mekanisme koping adaptif akan lebih efektif untuk mengurangi atau meredam ansietas sebaliknya jika individu menggunakan mekanisme koping maladaptif bisa memperburuk keadaan atau individu tersebut mempunyai potensi untuk kejadian sakit (Lau, 2019) 
Survei awal yang dilakukan dikelurahan dwi kora jalan Jawa maka ditemukan pasien dengan Ansietas akibat penyakit abses hati yang bernama Tn. P Di Kec Medan Helvetia.

\subsection{Rumusan masalah}

Berdasakan uraian latar belakang maka penulis membuat rumusan masalah sebagai berikut: "Asuhan Keperawatan psikososial pada Tn. P dengan masalah ansietas pada penderita abses hati”

\subsection{Tujuan Umum}

Agar penulis mampu melaksanakan dan menerapkan Asuhan Keperawatan psikososial dengan masalah ansietas pada penderita abses hati.

\subsection{Tujuan Khusus}
a. Mampu melakukan pengkajian pada Tn. P dengan ansietas.
b. Mampu merumuskan diagnose keperawatan pada Tn. P dengan ansietas.
c. Mampu menyusun rencana asuhan keperawatan pada Tn. P dengan ansietas.
d. Mampu melakukan implementasi pada Tn. P dengan ansietas.
e. Mampu melakukan evaluasi pada Tn. P dengan ansietas.

\subsection{Manfaat Penulisan}

a. Bagi kegiatan belajar mengajar

Diharapkan dapat dijadikan masukan untuk menambah dan meningkatkan pengetahuan dan wawasan bagi mahasiswa keperawatan serta pembaca pada umumnya dalam memberikan asuhan keperawatan.

b. Bagi praktik keperawatan

Diharapkan dapat memberikan asuhan keperawatan yang komprehensif dan berpikir kritis dalam melakukan asuhan terhadap klien khususnya dengan prioritas masalah kebutuhan rasa aman. 
c. Bagi kebutuhan klien

Diharapkan menambah wawasan dan informasi dalam mengatasi dan mengurangi rasa takut yang muncul akibat dari penyakit yang diderita. 


\section{BAB II}

\section{TINJAUAN PUSTAKA}

\subsection{Konsep Ansietas}

\subsubsection{Defenisi Ansietas}

Ansietas adalah perasaan ketakutan yang tidak memiliki penyebab yang jelas dan tidak didukung oleh situasi,kecemasan dapat dirasakan oleh setiap orang jika mengalami tekanan dan perasaan yang mendalam menyebabkan masalah kejiwaan dan berkembangan dalam jangka panjang (Pardede, Simanjuntak \& Manulu, 2020). Kecemasan merupakan suatu respon psikologis maupun fisiologis individu terhadap suatu keadaan yang tidak menyenangkan, atau reaksi atas situasi yang dianggap mengancam (Hulu \& Pardede, 2016).Kecemasan merupakan suatu keadaan perasaan gelisah, ketidaktentuan, ada rasa takut dari kenyataan atau persepsi ancaman sumber aktual yang tidak diketahui masalahnya (Pardede \& Simangunsong, 2020)

Ansietas merupakan keadaan emosi dan pengalaman subjektif individu. Keduanya adalah energi dan tidak dapat diamati secara langsung. Seorang perawat menilai pasien ansietas berdsarkan perilaku tertentu. Penting untuk diingat bahwa ansietas adalah bagian dari kehidupan sehari-hari. Ansietas adalah dasar kondisi manusia dan memberikan peringatan berharga. Bahkan kapsitas untuk menjadi ansietas diperlukan untuk bertahan hidup. Selain itu, seseorang dapat tumbuh dari ansietas jika seseorang berhasil berhadapan, berkaitan dengan, dan belajar dari menciptakan pengalaman ansieatas. (Stuart, 2016).

Ansietas adalah suatu perasaan takut akan terjadinya sesuatu yang disebabkan oleh antisipasi bahaya dan merupak sinyal yang membantu individu untuk bersiap mengambil tindakan menghadapi ancaman. Pengaruh tuntutan, persaingan, serta bencana yang terjadi dalam kehidupan dapat membawa dampak terhadap kesehatan fisik dan psikologis. Salah satu dampak psikologis yaitu ansietas atau kecemasan (Sutejo, 2018). 


\subsubsection{Etiology Ansietas}

Ansietas dapat diekspresikan secara langsung melalui timbulnya gejala atau mekanisme koping yang dikembangkan untuk menjelaskan ansietas (Stuart \& suddent, 2017) yaitu :

\section{Faktor predisposisi :}

a. Faktor psikoanalitik, ansietas adalah konflik emosional yang terjadi antara dua elemen kepribadian Id dan superego. Id mewakili dorongan insting dan impuls primitive seseorang, sedangkan superego mencermikan hati nurani seseorang dan dikendalikan oleh norma-norma budaya seseorang. Ego atau aku, berfungsi menengahi tuntutan dari dua elemen yang bertentangan dan fungsi ansietas adalah mengikatkan ego bahwa ada bahaya.

b. Faktor interpersonal, bahwa ansietas timbul dari perasaan takut terhadap tidak adanya penerimaan dan penolakan interposrnal. Ansietas juga berhubungan dengan perkembangan trauma, seperti perpisahan dan kehilangan, yang meninmbulkan kelemahan spesifik. Orang dengan harga diri rendah terutama mudah mengalami perkembangan ansietas yang berat.

c. Faktor perilaku, ansietas merupakan produk frustasi yaitu segala sesuatu yang menggangu kemampuan seseorang untuk mencapai tujuan yang diinginkan.

d. Kajian keluarga menunjukan bahwa ganguan ansietas biasanya terjadi dalam keluraga. Gangguan ansietas juga tumpang tindih antara gangguan ansietas dengan depresi

e. Kajian biologis menunjukan bahwa otak mengandung reseptor khusus untuk benzodiasepin, obat-obatan yang meningkatkan neuro regulatory inhibisi asam gama-aminobutirat (GABA), yang berperan penting dalam mekanisme biologis yang berhubungan dengan ansietas. Selain itu, kesehatan umum individu dan riwayat ansietas pada keluarga memiliki efek nyata predisposisi ansietas. Ansietas mungkin disertai dengan gangguan fisik dan selanjutnya menurunkan kemampuan individu untuk mengatasi stressor. 


\section{Faktor presipitasi}

Stressor pencetus dapat berasal dari sumber internal dan eksternal. Stressor pencetus dapat dikelompokan dalam dua kategori :

a. Ancaman terhadap intergritas fisik meliputi disabiltitas fisiologis yang akan terjadi atau penurunan kemampuan untuk melakukan aktifitas hidup sehari-hari

b. Ancaman terhadap sistim diri dapat membahayakan identitas, harga diri, dan fungsi social yang terintregasi pada individu.

\subsubsection{Tingkat Ansietas}

Menurut (Stuart, 2016) mengidentifikasi tingkat ansietas dengan penjelasan efeknya, yaitu :

\section{Ansietas Ringan}

Terjadi pada saat ada ketegangan dalam hidup sehari-hari. Selama ini seseorang waspada dan lapang tersepsi meningkat, kemampuan seseorang untuk melihat, medengar, dan menangkap dari sebelumnya. Jenis ansietas ini dapat memotivasi belajar, menghasilkan pertumbuhan, dan meningkatkan kreativitas.

\section{Ansietas Sedang}

Terjadi ketika seseorang hanya berfokus pada hal yang penting saja dan lapang persepsi menyempit. Sehingga kurang dalam melihat, mendengar, dan menangkap. Seseorang memblokir area tertentu tetapi masih mampu mengikuti perintah jika diarahkan untuk melakukannya.

\section{Ansietas Berat}

Terjadi ditandai dengan penurunan yang signifikan dilapang persepsi. Ansietas jenis ini cenderung memfokuskan pada hal detail dan tidak berfikir tentang hal lain. Semua perilaku ditunjukkan untuk mengurangi ansietas dan banyak arahan yag dibutuhkan untuk focus pada area lain.

\section{Panik}

Panik dikaitkan dengan rasa takut dan terror. Pada sebagian orang 
yang mengalami kepanikan tidak dapat melakukan hal-hal bahkan dengan arahan. Gejala panic yang sering muncul adalah peningkatan aktivitas motorik, penurunan kemampuan untuk berhubungan dnegan orang lain, persepsi yang menyempit dan kehilangn pemikiran yang rasional. Tingkat ansietas ini tidak dapat bertahan tanpa batas waktu, karena tidak kompatibel dengan kehidupan. Kondisi panic yang berkepanjangan akan mengakibatkan kelelahan dan kematian, tetapi panic dapat diobati dengan aman dan efektif.

\subsubsection{Gejala Klinis Ansietas}

Keluhan yang sering dotemukan pada seseorang yang mengalami ansietas antara lain sebagai berikut (Universitas Indonesia, 2016) :

1. Cemas, khawatir, firasat buruk, takut akan pikirannya sendiri, dan mudah tersinggung.

2. Merasa tegang, tidak tenang, gelisah, dan mudah terkejut.

3. Takut sendirian,takut pada keramaian, dan banyak orang.

4. Gangguan pola tidur dan muncul mimpi menegangkan

5. Keluhan somatic, misalnya terjadi rasa sakit pada otot dan tulang, pendengaran berdengung (tiritus, berdebar-debar, sesak napas, gangguan pencernaan, gangguan perkemihan, dan sakit kepala)

\subsubsection{Mekanisme Koping}

Ketika pasien mengalami ansietas, individu menggunakan bermacammacammekanisme koping untuk mencoba mengatasinya. Dalam bentuk ringan ansietas bentuk ringan ansietas dapat di atasi dengan menangis, tertawa, tidur, olahraga atau merokok. Bila terjadi ansietas berat sampai panik akan terjadi ketidakmampuan mengatasi ansietas secara konstruktif merupakan penyebab utama perilaku yang patologis, individu akan menggunakan energy yang lebih besar untuk dapat mengatasi ancaman tersebut.

Mekanisme koping untuk mengatasi ansietas adalah 
1. Reaksi yang berorientasi pada tugas (task oriented reaction) Merupakan pemecahan masalah secara sadar yang digunakan untuk menanggulangi ancaman stressor yang ada secara realistis yaitu:

a. Perilaku menyerang (Agresif) Biasanya digunakan individu untuk mengatasi rintangan agar memenuhi kebutuhan.

b. Perilaku menarik diri Digunakan untuk menghilangkan sumber ancaman baik secara fisik maupun psikologis.

c. Perilaku kompromi Digunakan untuk merubah tujuan yang akan dilakukan atau mengorbankan kebutuhan personal untuk mencapai tujuan.

2. Mekanisme pertahanan ego (Ego oriented reaction) Mekanisme ini membantu mengatasi ansietas ringan dan sedang yang digunakan untuk melindungi diri dan dilakukan secara sadar untuk mempertahankan keseimbangan. Mekanisme pertahanan ego:

a. Disosiasi adalah pemisahan dari proses mental atau perilaku dari kesadaran atau identitasnya.

b. Identifikasi (identification) adalah proses dimana seseorang untuk menjadi yang ia kagumi berupaya dengan mengambil/meniru pikiranpikiran, perilaku dan selera orang tersebut.

c. Intelektualisasi (intellectualization) adalah penggunaan logika dan alasan yang berlebihan untuk menghindari pengalaman yang mengganggu perasaannya.

d. Introjeksin (introjection) adalah suatu jenis identifikasi yang dimana seseorang mengambil dan melebur nilai-nilai dan kualitas seseorang atau suatu kelompok kedalam struktur egonya sendiri, berupa hati nurani, contohnya rasa benci atau kecewa terhadap kematian orang yang dicintai, dialihkan dengan cara menyalahkan diri sendiri.

e. Kompensasi adalah proses dimana seseorang memperbaiki penurunan citra diri dengan secara tegas menonjolkan keistimewaan/kelebihan yang dimilikinya. Penyangkalan (Denial) adalah menyatakan ketidaksetujuan terhadap realitas dengan 
mengingkari realitas tersebut. Mekanisme pertahanan ini adalah penting, sederhana, primitif.

f. Pemindahan (displacement) adalah pengalihan emosi yang semula ditujukan pada seseorang/benda kepada orang lain/benda lain yang biasanya netral atau kurang mengancam dirinya.

g. Isolasi adalah pemisahan unsur emosional dari suatu pikiran yang menggangu dapat bersifat sementara atau berjangka lama.

h. Proyeksi adalah pengalihan buah pikiran atau impuls pada diri sendiri kepada orang lain terutama keinginan, perasaan emosional dan motivasi yang tidak dapat ditoleransi.

i. Rasionalisasi adalah mengemukakan penjelasan yang tampak logis dan dapat diterima masyarakat untuk membenarkan perasaan perilaku dan motif yang tidak dapat diterima.

j. Reaksi formasi adalah pengembangan sikap dan pola perilaku yang ia sadari yang bertentangan dengan apa yang sebenarnya ia rasakan atau ingin dilakukan.

k. Regresi adalah kemunduran akibat stress terhadap perilaku dan merupakan ciri khas dari suatu taraf perkembangan yang lebih dini.

1. Represi adalah pengenyampingkan secara tidak sadar tentangtentang pikiran, ingatan yang menyakitkan atau bertentangan ,dari kesadaran seseorang merupakan pertahanan ego yang primer yang cenderung diperkuat oleh mekanisme lain.

\subsection{Konsep Asuhan Keperawatan}

\subsubsection{Pengkajian}

\section{Faktor Predisposisi}

Berbagai teori telah dikembangkan untuk menjelaskan asal ansietas (Waryuningsih,2021) :

\section{a. Teori Psikoanalitik}

Ansietas adalah konflik emosional yang terjadi antara dua elemen kepribadian, ID dan superego. ID mewakili dorongan insting dan impuls primitif seseorang, sedangkan superego mencerminkan hati nurani seseorang dan dikendalikan oleh 
norma- norma budaya seseorang. Ego atau Aku, berfungsi menengahi hambatan dari dua elemen yang bertentangan dan fungsi ansietas adalah mengingatkan ego bahwa ada bahaya

\section{b. Teori Interpersonal}

Ansietas timbul dari perasaan takut terhadap tidak adanya penerimaan dari hubungan interpersonal. Ansietas juga berhubungan dengan perkembangan, trauma seperti perpisahan dan kehilangan sehingga menimbulkan kelemahan spesifik.Orang dengan harga diri rendah mudah mengalami perkembangan ansietas yang berat.

\section{c. Teori Perilaku}

Ansietas merupakan produk frustasi yaitu segala sesuatu yang mengganggu kemampuan seseorang untuk mencapai tujuan yang diinginkan.Daftar tentang pembelajaran meyakini bahwa individu yang terbiasa dalam kehidupan dininya dihadapkan pada ketakutan yng berlebihan lebih sering menunjukkan ansietas pada kehidupan selanjutnya.

\section{d. Kajian Keluarga}

Menunjukkan bahwa gangguan ansietas merupakan hal yang biasa ditemui dalam suatu keluarga.Ada tumpang tindih dalam gangguan ansietas dan antara gangguan ansietas dengan depresi.

\section{e. Kajian Biologis}

Menunjukkan bahwa otak mengandung reseptor khusus benzodiazepine. Reseptor ini mungkin membantu mengatur ansietas penghambat dalam aminobutirik. Gamma neuroregulator (GABA) juga mungkin memainkan peran utama dalam mekanisme biologis berhubungan dengan ansietas sebagaimana halnya endorfin. Selain itu telah dibuktikan kesehatan umum seseorang mempunyai akibat nyata sebagai predisposisi terhadap ansietas. Ansietas mungkin disertai dengan gangguan fisik dan selanjutnya menurunkan kapasitas seseorang 
untuk mengatasi stressor.

\section{Faktor Presipitasi}

Stressor pencetus mungkin berasal dari sumber internal atau eksternal. Stressor pencetus dapat dikelompokkan menjadi 2 kategori (Pratiwi, Widianti \& Solehati, 2017):

a. Ancaman terhadap integritas seseorang meliputi ketidakmampuan fisiologis yang akan datang atau menurunnya kapasitas untuk melakukan aktifitas hidup sehari- hari.

b. Ancaman terhadap sistem diri seseorang dapat membahayakan identitas, harga diri dan fungsi sosial yang terintegrasi seseorang.

\section{Perilaku}

Kecemasan dapat diekspresikan secara langsung melalui perubahan fisiologi dan perilaku dan secara tidak langsung melalui timbulnya gejala atau mekanisme koping dalam upaya melawan kecemasan. Intensitas perilaku akan meningkat sejalan dengan peningkatan tingkat kecemasan.

a. Respon Fisiologis Terhadap Ansietas

\begin{tabular}{|l|l|}
\hline Sistem Tubuh & \multicolumn{1}{|c|}{ Respons } \\
\hline Kardiovaskuler & - Palpitasi. \\
& - Jantung berdebar. \\
& - Tekanan darah meningkat dan denyut nadi menurun. \\
& - Rasa mau pingsan dan pada akhirnya pingsan. \\
\hline Pernafasan & - Napas cepat. \\
& - Pernapasan dangkal. \\
& - Rasa tertekan pada dada. \\
& - Pembengkakan pada tenggorokan. \\
& - Terengah-engah. \\
\hline Neuromuskular & - Peningkatan reflek. \\
& - Reaksi kejutan. \\
& - Insomnia. \\
& - Ketakutan. \\
\hline
\end{tabular}




\begin{tabular}{|c|c|}
\hline & $\begin{array}{l}\text { - } \text { Gelisah. } \\
\text { - Wajah tegang. } \\
\text { - Kelemahan secara umum. } \\
\text { - Gerakan lambat. } \\
\text { - Gerakan yang janggal. }\end{array}$ \\
\hline Gastrointestinal & $\begin{array}{l}\text { - } \text { Kehilangan nafsu makan. } \\
\text { - } \text { Menolak makan. } \\
\text { - } \text { Perasaan dangkal. } \\
\text { - } \text { Rasa tidak nyaman pada abdominal. } \\
\text { - Rasa terbakar pada jantung. } \\
\text { - Nausea. } \\
\text { - Diare. }\end{array}$ \\
\hline Perkemihan & $\begin{array}{l}\text { - } \quad \text { Tidak dapat menahan kencing. } \\
\text { - } \quad \text { Sering kencing. }\end{array}$ \\
\hline Kulit & $\begin{array}{l}\text { - } \text { Rasa terbakar pada mukosa. } \\
\text { - } \text { Berkeringat banyak pada telapak tangan. } \\
\text { - } \text { - Patal-gatal. } \\
\text { - Muka pucan panas atau dingin pada kulit. } \\
\text { Mekeringat diseluruh tubuh. }\end{array}$ \\
\hline
\end{tabular}

b. Respon Perilaku Kognitif

\begin{tabular}{|c|c|}
\hline Sistem & Respons \\
\hline Perilaku & $\begin{array}{l}\text { - } \text { Gelisah. } \\
\text { - } \text { Ketegangan fisik. } \\
\text { - } \text { Gugup. } \\
\text { - } \text { Bicara cepat. } \\
\text { - Tidak ada koordinasi. } \\
\text { - Kecenderungan untuk celaka. } \\
\text { - Menarik diri. } \\
\text { - Menghindar. } \\
\text { - Terhambat melakukan aktifitas. }\end{array}$ \\
\hline Kognitif & $\begin{array}{l}\text { - } \text { Gangguan perhatian. } \\
\text { - } \text { Konsentrasi hilang. } \\
\text { - } \text { Pelupa. } \\
\text { - Salah tafsir. } \\
\text { - } \text { Adanya bloking pada pikiran. } \\
\text { - } \text { Krenurunnya lahan persepsi. } \\
\text { - Bingung. }\end{array}$ \\
\hline
\end{tabular}




\begin{tabular}{|c|c|}
\hline & $\begin{array}{l}\text { - Khawatir yang berlebihan. } \\
\text { - Hilang menilai objektifitas. } \\
\text { - Takut akan kehilangan kendali. } \\
\text { - Takut yang berlebihan. }\end{array}$ \\
\hline Afektif & $\begin{array}{l}\text { - } \text { Mudah terganggu. } \\
\text { - Tidak sabar. } \\
\text { - Gelisah. } \\
\text { - } \text { Tegang. } \\
\text { - Nerveus. } \\
\text { - Ketakutan. } \\
\text { - Alarm. } \\
\text { - Tremor. } \\
\text { - Gugup. } \\
\text { - Gelisah. }\end{array}$ \\
\hline
\end{tabular}

\section{Sumber Koping}

Individu dapat mengalami stress dan ansietas dengan menggerakkan sumber koping tersebut di lingkungan. Sumber koping tersebut sebagai modal ekonomok, kemampuan penyelesaian masalah, dukungan sosial dan keyakinan budaya dapat membantu seseorang mengintegrasikan pengalaman yang menimbulkan stress dan mengadopsi strategi koping yang berhasil(Sulastri, Trilianto \& Ermaneti,2019).

\section{Mekanisme Koping}

Ketika mengalami ansietas individu menggunakan berbagai mekanisme koping untuk mencoba mengatasinya dan ketidakmampuan mengatasi ansietas secara konstruktif merupakan penyebab utama terjadinya perilaku patologis. Ansietas tingkat ringan sering ditanggulangi tanpa yang serius. Tingkat ansietas sedang dan berat menimbulkan 2 jenis mekanisme koping(Sumoked, Wowiling\& Rompas, 2019) :

a. Reaksi yang berorientasi pada tugas, yaitu upaya yang disadari dan berorientasi pada tindakan untuk memenuhi secara realitis tuntutan situasi stress. 
b. Mekanisme pertahanan ego, membantu mengatasi ansietas ringan dan sedang, tetapi jika berlangsung pada tingkat sadar dan melibatkan penipuan diri dan distorsi realitas, maka mekanisme ini dapat merupakan respon maladaptif terhadap stress.

\subsubsection{Diagnosa Keperawatan}

Adapun diagnosa yang biasanya muncul adalah :

1. Koping Individu Tidak Efektif

2. Kecemasan

3. Ketidakberdayaan

4. Isolasi Sosial

5. Perubahan Proses Berfikir

\subsubsection{Intervensi Keperawatan}

\section{Kecemasan}

Tujuan :

- Klien mampu mengenal pengertian penyebab tanda gejala dan akibat

- Klien mampu mengetahui cara mengatasi ansietas

- Klien mampu mengatasi ansietas dengan melakukan latihan relaksasi tarik nafas dalam

- Klien mampu mengatasi ansietas dengan melakukan latihan distraksi

- Klien mampu mengatasi ansietas dengan melakukan hipnotis lima jari

- Klien mampu merasakan manfaat dari latihan yang dilakukan

- Klien mampu membedakan perasaan sebelum dan sesudah latihan 
Tindakan :

a. Kaji tanda dan gejala ansietas dan kemampuan klien mengurangi kecemasan

b. Jelaskan tanda dan gejala, penyebab dan akibat dari kecemasan

c. Latihan cara mengatasi kecemasan :

1) Teknik relaksasi napas dalam

2) Distraksi : bercakap-cakap hal positif

3) Hipnotis 5 jari fokus padahal-hal yang positif

d. Bantu klien melakukan latihan sesuai dengan jadwal kegiatan.

\section{Ketidakberdayaan}

Tujuan :

- Klien mampu mengenali ketidakberdayaan yang dialaminya

- Klien mampu mengontrol ketidakberdayaan dengan berpikir positif

- Klien mampu mengontrol ketidakberdayaan dengan berpartisipasi dalam pengambilan keputusan yang berkenaan dengan perawatannya sendiri

- Klien mampu mengontrol ketidakberdayaan melalui peningkatan kemampuan mengendalikan situasi yang masih bisa dilakukan pasien

- Tindakan :

a. Diskusikan tentang penyebab dan perilaku akibat ketidakberdayaan

b. Bantu klien untuk mengekspresikan perasaannya dan identifikasi area-area situasi kehidupan yang tidak berada dalam kemampuannya untuk mengontrol

c. Bantu klien untuk mengidentifikasi faktor-faktor yang dapat berpengaruh terhadap ketidakberdayaan

d. Identifikasi pemikiran yang negative dan bantu untuk menurunkan melalaui interupsi atau subtitusi

e. Latih mengembangkan harapan positif (afirmasi positif) 
f. Latihan mengontrol perasaan ketidakberdayaan melalui peningkatan kemampuan mengendalikan situasi yang masih bisa dilakukan pasien (bantu klien mengidentifikasi area-area situasi kehidupan yang dapat dikontrolnya. Dukung kekuatan-kekuatan diri yang dapat diidentifikasi oleh klien). Misalnya klien masih mampu menjalankan peran sebagai ayah meskipun sedang sakit.

\section{Gangguan pola tidur}

Tujuan :

- Klien mampu mengenal masalah pola tidur

- Klien mampu melakukan upaya mengatasi gangguan pola tidur

- Klien mampu beristirahat secara teratur

Tindakan :

a. Menjelaskan tanda dan gejala, penyebab dan akibat gangguan pola tidur

b. Mengidentifikasi tanda dan gejala, penyebab dan akibat gangguan pola tidur

c. Menjelaskan masalah gangguan tidur kepada klien

d. Menjelaskan dan melatih klien mengatasi gangguan pola tidur

e. Mengidentifikasi kemampuan klien dalam upaya mengatasi gangguan pola tidur

f. Mendiskusikan upaya mengatasi gangguan pola tidur

g. Melatih klien relaksasi untuk mengatasi gangguan pola tidur dan memasukan kegiatannya dalam jadwal kegiatan harian

h. Menganjurkan klien istirahat secara teratur 
BAB 3

TINJAUN KASUS

\subsection{Pengkajian Keperawatan}

\begin{tabular}{|l|l|}
\hline Nama : Tn. P & Kondisi saat MRS: Pasien mengeluh gelisah dan susah tidur dikarenakan \\
Usia : 29 tahun & memikirkan penyakit yang di deritanya. \\
Tahun no reg : - & \\
Ruangan : - & $\begin{array}{c}\text { Kondisi saat ini : } \\
\text { Tgl masuk rs: - } \\
\text { Tgl pengkajian : } 3 \text { oktober } 2021\end{array}$ \\
$\begin{array}{l}\text { Alamat : Jalan jawa Gg. Radio } \\
\text { kec. Medan Hevetia }\end{array}$ & didapatkan TD : 100,60 mmHg \\
\hline
\end{tabular}

\subsubsection{Faktor Predisposisi Dan Faktor Presipitasi}

\begin{tabular}{|c|c|c|c|c|}
\hline \multirow[t]{2}{*}{ Faktor predisposisi } & \multicolumn{3}{|l|}{ Faktor presipitasi } & \multirow[t]{2}{*}{ STRESSOR } \\
\hline & Nature & Origin & $\begin{array}{l}\text { Number } \& \\
\text { Timing }\end{array}$ & \\
\hline $\begin{array}{l}\text { Biologis: klien mengatakan pernah ada riwayat hipertensi } 1 \\
\text { tahun yang lalu. }\end{array}$ & $\begin{array}{l}\text { - Saat dilakukan } \\
\text { pemeriksaan tingkat } \\
\text { kesadaran } \\
\text { composmentis } \\
\text { dengan GCS : } 15 \\
\text { 0(E4V6M6) } \\
\text { - } \mathrm{TD}: 100 / 60 \mathrm{mmHg}\end{array}$ & Internal & $\begin{array}{l}\text { Saat } \\
\text { dilakukan } \\
\text { pengkajian }\end{array}$ & - Abses Hati \\
\hline
\end{tabular}




\begin{tabular}{|c|c|c|c|c|}
\hline & $\begin{array}{ll}\text { - } & \mathrm{N}: 80 \mathrm{x} / \text { menit } \\
\text { - } & \mathrm{P}: 20 \mathrm{x} / \text { menit } \\
\text { - } & \mathrm{S}: 37,7 \mathrm{c} \\
\end{array}$ & & & \\
\hline $\begin{array}{l}\text { Psikologis : } \\
\text { 1. Tn. P memiliki kepribadia yang terbuka setiap ada } \\
\text { masalah akan dibicarakan } \\
\text { 2. Tn. P merasa cemas dan khawatir takut penyakitnya } \\
\text { semakin parah dan tidak sembuh }\end{array}$ & 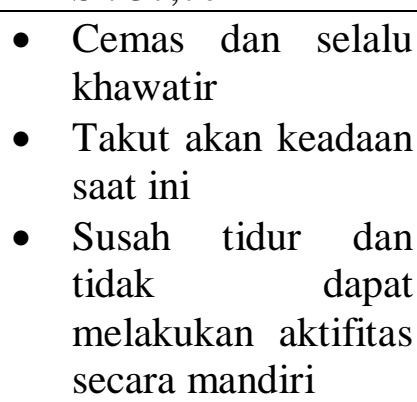 & Internal & $\begin{array}{l}\text { Saat } \\
\text { dilakukan } \\
\text { pengkajian }\end{array}$ & $\begin{array}{l}\text { - Cemas, takut } \\
\text { panikan, kwatir }\end{array}$ \\
\hline $\begin{array}{l}\text { Sosiocultural : } \\
\text { 1. Tn. P seorang laki-laki umur } 29 \text { tahun } \\
\text { 2. Tn . P menikah dan memiliki } 2 \text { orang anak } \\
\text { 3. Tn. P merupakan ayah/kepala rumah tangga } \\
\text { 4. Sebelumnya Tn. P aktif terlibat dalam kegiatan } \\
\text { dilingkungan tempat tinggal dan sering bersosialisasi } \\
\text { bersama warga yang lain } \\
\text { 5. Tn. P beragama Kristen dan taat menjalankan ibadah } \\
\text { 6. Tn.P jarang check up penyakitnya }\end{array}$ & & & & \\
\hline \multicolumn{5}{|c|}{$\begin{array}{l}\text { Tn. P Setela } \\
2 \text { orang } \\
\text { perempuan } \\
\text { sudah kelas }\end{array}$} \\
\hline
\end{tabular}




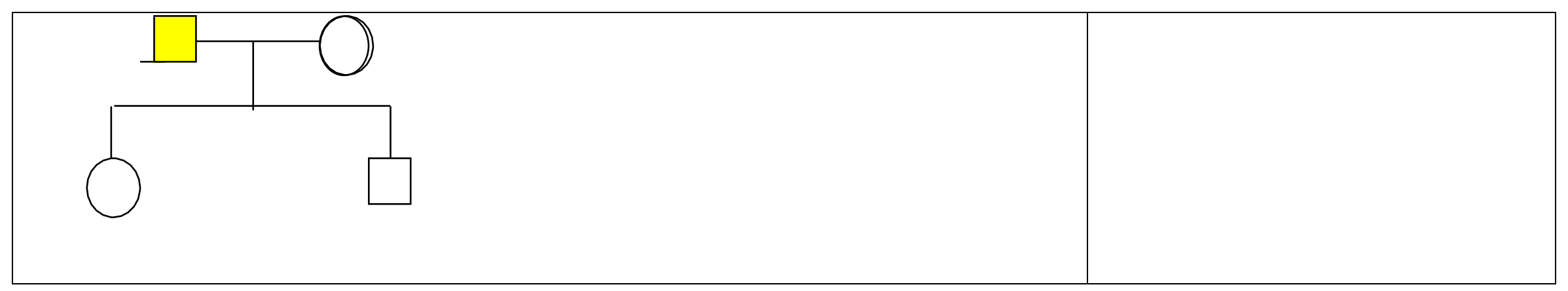




\subsubsection{Penilaian (Respon)Terhadap Stressor}

\begin{tabular}{|c|c|c|c|c|c|c|}
\hline STRESSOR & KOGNITIF & AFEKTIF & FISIOLOGIS & PERILAKU & SOSIAL & $\begin{array}{c}\text { DIAGNOSA } \\
\text { KEPERAWATAN }\end{array}$ \\
\hline $\begin{array}{l}\text { BIOLOGIS } \\
\text { - (Abses } \\
\text { Hati) }\end{array}$ & $\begin{array}{l}\text { - Menurut Tn. P } \\
\text { penyakit } \\
\text { Abses hati } \\
\text { diakibatkan } \\
\text { karena makan } \\
\text { makanan } \\
\text { sembarangan } \\
\text { atau makanan } \\
\text { mentah atau } \\
\text { setengah } \\
\text { masak } \\
\text { - Menganggap } \\
\text { penyakit } \\
\text { yang diderita } \\
\text { serius } \\
\text { Tidak tahu apa } \\
\text { yang harus } \\
\text { dilakukan } \\
\text { untuk } \\
\text { penyakitnya }\end{array}$ & $\begin{array}{l}\text { Tn. P } \\
\text { merasa } \\
\text { sedih dan } \\
\text { bingung } \\
\text { dengan } \\
\text { kondisi } \\
\text { penyakitny } \\
\text { a }\end{array}$ & $\begin{array}{l}\text { - } \text { Pusing } \\
\text { - Sulit tidur } \\
\text { - Tidak } \\
\text { nafsu } \\
\text { makan } \\
\text { - Tn.P } \\
\text { tampak } \\
\text { lemas } \\
\text { Pemeriksaa } \\
\text { n TTV } \\
\text { TD: } 100 / 60 \\
\text { mmhg } \\
\text { N : } 80 \text { x / } \\
\text { menit } \\
\text { P : } 20 \quad \text { x / } \\
\text { menit } \\
\text { S: } 37,7^{0} \mathrm{C}\end{array}$ & $\begin{array}{l}\text { - } \text { Tn..P } \\
\text { jarang } \\
\text { check-up } \\
\text { kerumah } \\
\text { sakit } \\
\text { - Ekspres } \\
\text { i muka } \\
\text { lesu dan } \\
\text { lemas } \\
\text { - Tn.P } \\
\text { tampak } \\
\text { lemas dan } \\
\text { khawatir }\end{array}$ & $\begin{array}{l}\text { - Pasien } \\
\text { mendatangi } \\
\text { dan } \\
\text { menggunaka } \\
\mathrm{n} \text { fasilitas } \\
\text { kesehatan } \\
\text { yang ada } \\
\text { untuk } \\
\text { mencari } \\
\text { kesembuhan } \\
\text { terhadap } \\
\text { masalah yang } \\
\text { dihadapi saat } \\
\text { ini }\end{array}$ & - Ansietas \\
\hline $\begin{array}{l}\text { PSIKOLOG } \\
\text { IS }\end{array}$ & \multirow{2}{*}{$\begin{array}{lr}\text { Merasa } & \text { cemas } \\
\text { dengan } & \\
\text { keadaan } & \text { saat } \\
\text { ini, } & \text { takut }\end{array}$} & \multirow{2}{*}{$\begin{array}{l}\text { - } \text { Merasa } \\
\text { kesal } \\
\text { dengan } \\
\text { penyakitnya }\end{array}$} & \multirow{2}{*}{$\begin{array}{l}\text { - } \\
\text { Napas } \\
\text { pendek, } \\
\text { nyeri pada } \\
\text { bagian ulu }\end{array}$} & \multirow{2}{*}{$\begin{array}{l}\text { - Mencerit } \\
\text { akan } \\
\text { semua } \\
\text { apa yang }\end{array}$} & \multirow{2}{*}{$\begin{array}{l}\text { - } \text { Hubungan } \\
\text { Tn.Pdengan } \\
\text { istri baik } \\
\text { baik }\end{array}$} & \multirow[t]{2}{*}{ - Ansietas } \\
\hline $\begin{array}{l}\text { - Klien merasa } \\
\text { cemas }\end{array}$ & & & & & & \\
\hline
\end{tabular}




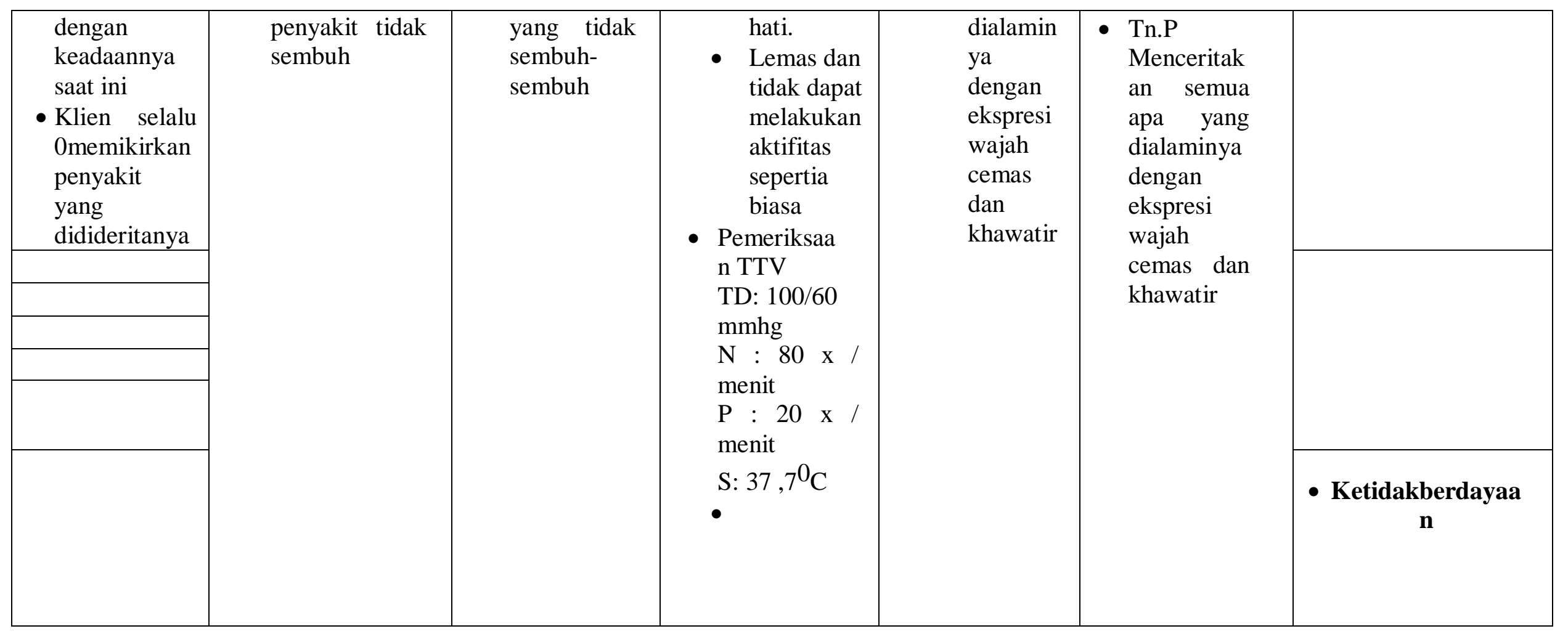




\begin{tabular}{|c|c|c|c|c|c|c|}
\hline \begin{tabular}{l}
\multicolumn{1}{c}{ SOSIAL } \\
BUDAYA \\
Sering \\
gelisah dan \\
cemas karena \\
memikirkan \\
penyakitnya \\
dan memikira \\
anak serta \\
istrinya.
\end{tabular} & $\begin{array}{l}\text { - Tn.P merasa } \\
\text { tidak berdaya } \\
\text { dengan } \\
\text { keadaannya dan } \\
\text { tidak dapat } \\
\text { berkerja lagi } \\
\text { untuk } \\
\text { memenuhi } \\
\text { kebutahan anak } \\
\text { dan istrinya } \\
\text { - Setiap malam } \\
\text { susah tidar } \\
\text { dan bahkan } \\
\text { tidak dapat } \\
\text { tidur } \\
\text { dikarenakan } \\
\text { selalu } \\
\text { memikirkan } \\
\text { keadaan nya. }\end{array}$ & $\begin{array}{l}\text { - Merasa } \\
\text { khawatir } \\
\text { dan sedih } \\
\text { kepada } \\
\text { suami yang } \\
\text { merawatny } \\
\text { a setiap } \\
\text { hari } \\
\text { - Merasa } \\
\text { bersalah } \\
\text { karena } \\
\text { merasa } \\
\text { merepotka } \\
\text { n suami } \\
\text { - Merasa } \\
\text { bosan } \\
\text { dengan } \\
\text { keadaan } \\
\text { sekarang }\end{array}$ & $\begin{array}{l}\text { - } \text { Nyeri uluh } \\
\text { hati } \\
\text { - } \text { Mual } \\
\text { - Mulut } \\
\text { tampak } \\
\text { kering } \\
\text { - Sulit tidur } \\
\text { - Tidak } \\
\text { nafsu } \\
\text { makan } \\
\text { - Tn. } \\
\text { tampak P } \\
\text { lemas } \\
\text { - Wajah Tn. P } \\
\text { tampak } \\
\text { pucat }\end{array}$ & $\begin{array}{l}\text { - Kontak } \\
\text { mata ada } \\
\text { tapi tidak } \\
\text { bertahanla } \\
\text { ma } \\
\text { - Volume } \\
\text { suara } \\
\text { mengecil } \\
\text { - Tn. P } \\
\text { tampak } \\
\text { gelisah } \\
\text { dan } \\
\text { ceemas }\end{array}$ & $\begin{array}{l}\text { - Hubungan } \\
\text { Tn. P. P } \\
\text { dengan istri } \\
\text { dan anak } \\
\text { baik } \\
\text { - Hubungan } \\
\text { Tn. P. P } \\
\text { dengan } \\
\text { petugas } \\
\text { kesehatan } \\
\text { baik } \\
\text { - Tn. P tetap } \\
\text { mengikuti } \\
\text { program } \\
\text { pengobatan }\end{array}$ & - $\begin{array}{l}\text { Gangguan pola } \\
\text { tidur }\end{array}$ \\
\hline
\end{tabular}




\subsubsection{Sumber Koping}

\begin{tabular}{|c|c|c|c|c|c|}
\hline $\begin{array}{c}\text { DIAGNOSA } \\
\text { KEPERAWATAN }\end{array}$ & $\begin{array}{c}\text { PERSONAL } \\
\text { ABILITY }\end{array}$ & $\begin{array}{l}\text { SOSIAL } \\
\text { SUPPORT }\end{array}$ & $\begin{array}{l}\text { MATERIAL } \\
\text { ASSETS }\end{array}$ & $\begin{array}{l}\text { POSITIE } \\
\text { BELIEFS }\end{array}$ & TERAPI \\
\hline Ansietas & $\begin{array}{l}\text { - Tn. P mampu } \\
\text { mengungkapkan } \\
\text { perasaancemas } \\
\text { - Tn. P mengatakan bila } \\
\text { cemasnya memuncak } \\
\text { maka ia akan berdoa } \\
\text { kepada tuhan }\end{array}$ & 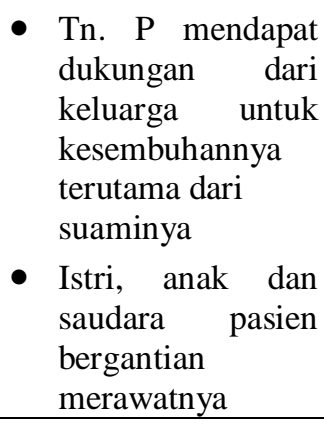 & 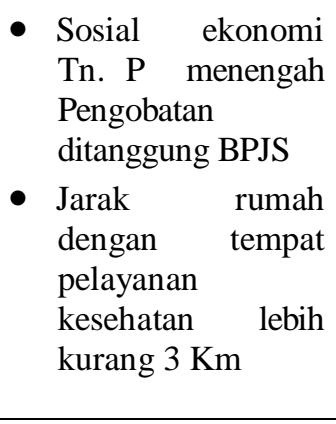 & $\begin{array}{l}\text { - Tn. P percaya bahwa } \\
\text { petugas kesehatan } \\
\text { akan membantunya } \\
\text { - Tn. P berharap cepat } \\
\text { sembuh agar tidak } \\
\text { merepotkan } \\
\text { Istri dan anaknya }\end{array}$ & $\begin{array}{l}\text { Terapi spesialis: } \\
\text { - } \text { Relaksasi } \\
\text { progresif } \\
\text { - } \begin{array}{l}\text { Teknik terapi } \\
\text { relaksi } \\
\text { autogenitik }\end{array}\end{array}$ \\
\hline
\end{tabular}




\begin{tabular}{|c|c|c|}
\hline $\begin{array}{l}\text { Penampilan peran } \\
\text { tidak efektif }\end{array}$ & $\begin{array}{l}\text { - Tn. P dapat } \\
\text { menyebutkan } \\
\text { penyebab } \\
\text { penampilan peran } \\
\text { tidak efektif } \\
\text { - Tn. P P } \\
\text { menganggap } \\
\text { istri tidak } \\
\text { mampu sebagai } \\
\text { pengganti } \\
\text { akibat kondisi } \\
\text { yang berubah }\end{array}$ & $\begin{array}{l}\text { - Tn. P selalu } \\
\text { berdoa untuk } \\
\text { kesembuhan } \\
\text { penyakitnya } \\
\text { - Tn. P yakin, bila } \\
\text { ia mengikuti } \\
\text { petunjuk dan } \\
\text { saran dari petugas } \\
\text { kesehatan maka ia } \\
\text { akan cepat } \\
\text { sembuh istri } \\
\text { Tn. P yakin istri } \\
\text { dan keluarga } \\
\text { mendukung } \\
\text { supaya lekas } \\
\text { sembuh } \\
\text { Tn. P percaya } \\
\text { bahwa petugas } \\
\text { kesehatan akan } \\
\text { membantunya } \\
\text { Tn. P berharap } \\
\text { cepat sembuh } \\
\text { agar tidak } \\
\text { merepotkan } \\
\text { istrinya }\end{array}$ \\
\hline
\end{tabular}




\begin{tabular}{|c|c|c|c|c|c|}
\hline Kurang pengetahuan & $\begin{array}{l}\text { - Tn. P mampu mengenal } \\
\text { dan menilai Komplikasi } \\
\text { dari penyakitnya } \\
\text { - Tn. P mampu melatih } \\
\text { cara hidup sehat }\end{array}$ & 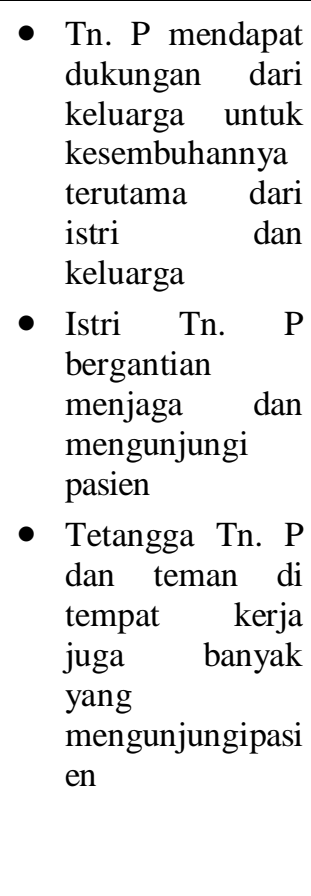 & $\begin{array}{l}\text { - Sosial ekonomi } \\
\text { Tn. P menengah } \\
\text { Tn. P tinggal di } \\
\text { rumah sendiri, } \\
\text { rumah } \\
\text { permanen } \\
\text { - Sarana dan } \\
\text { prasarana } \\
\text { tersedia } \\
\text { Biaya } \\
\text { pengobatan } \\
\text { ditanggung oleh } \\
\text { asuransi BPJS } \\
\text { Jarak rumah .Tn. } \\
\text { P dengan tempat } \\
\text { pelayanan } \\
\text { kesehatan }\end{array}$ & $\begin{array}{l}\text { - Tn. P percaya bahwa } \\
\text { petugas kesehatan } \\
\text { akan membantunya } \\
\text { - Tn. P berharap cepat } \\
\text { sembuh agar tidak } \\
\text { merepotkan } \\
\text { suaminya } \\
\text { - Tn. P selalu berdoa } \\
\text { untuk kesembuhan } \\
\text { penyakitnya } \\
\text { Tn. P yakin, bila ia } \\
\text { mengikuti petunjuk } \\
\text { dan saran dari } \\
\text { petugas kesehatan } \\
\text { maka ia akan cepat } \\
\text { sembuh } \\
\text { Tn. P yakin istri } \\
\text { dan keluarga } \\
\text { mendukung } \\
\text { supaya lekas } \\
\text { sembuh }\end{array}$ & $\begin{array}{l}\text { Terapi generalis: } \\
\text { - } \text { SP 1-2 kurang } \\
\text { pengetahuan } \\
\text { - } \text { Terapi } \\
\text { relaksai otot } \\
\text { progesif dan } \\
\text { teknik } \\
\text { relaksasi } \\
\text { autogenitik }\end{array}$ \\
\hline
\end{tabular}




\subsubsection{Mekanisme Koping}

\begin{tabular}{|c|c|}
\hline \multicolumn{1}{|c|}{ HAL YANG } & \multicolumn{1}{c|}{ ANALISA } \\
\hline \multicolumn{1}{|c|}{ DILAKUKAN } & $\begin{array}{l}\text { Konstruktif: } \\
\checkmark \text { Tn. P mengatakan bila ada masalah, maka ia akan } \\
\text { membicarakan dengan istri dan keluarga untuk } \\
\text { mencari jalan keluarnya }\end{array}$ \\
$\begin{array}{l}\text { Tn. P mengatakan bila ada masalah, maka ia akan membicarakan } \\
\text { dengan istri dan keluarga untuk mencari jalan keluarnya }\end{array}$ & $\begin{array}{l}\checkmark \text { Tn. P taat menjalankan ibadah sesuai } \\
\text { dengan keyakinannya }\end{array}$ \\
- Bila sakit Tn. P berobat ke pelayanan kesehatan & $\begin{array}{l}\text { Tn. P selalu berdoa kepada Tuhan } \\
\text { untuk kesembuhannya. }\end{array}$ \\
- Tn. P taat menjalankan ibadah sesuai dengan keyakinannya
\end{tabular}




\subsubsection{Status Mental}

\begin{tabular}{|l|l|}
\hline 1. Penampilan & Bersih, rapi, tidak tercium bau, Tn. P tampak lemas \\
\hline 2. Pembicaraan & Ramah dan mau menceritakan yang dialami tapi terkadang ekspresi wajah sedih \\
\hline 3. Aktivitas motoric & Mampu berinteraksi saat diajak berbicara \\
\hline 4. Interaksi selamawawancara & Ada kontak mata saat wawancara \\
\hline 5. Alam perasaan & Klien selalu merasa cemas dan khawatir dengan penyakitnya \\
\hline 6. Afek & Sesuai dengan emosi \\
\hline 7. Persepsi & Tidak ada gangguan persepsi dan sensori \\
\hline 8. Isi piker & Tidak ada gangguan isi piker \\
\hline 9. Proses piker & Tidak ada gangguan proses piker \\
\hline 10. Tingkat kesadaran & Normal \\
\hline 11. Daya ingat & Normal \\
\hline 12. Kemampuan berhitung & Kemampuan berhitung cukup baik/kemampuan berhitung baik \\
\hline 13. Penilaian & Klien mampu mengambil keputusan berobat saat merasa sakit \\
\hline 14. Daya tilik diri & $\begin{array}{l}\text { Tn. P menyadari bahwa saat ini ia sdang sakit, Tn. P hanya bisa berd0oa supaya lekas sembuh agar } \\
\text { tidak terus merepotkan suaminya. Tn. P menyadari ia memiliki istri, anak-anak dan keluarga yang } \\
\text { menyayanginya dan mendukung kesembuhannya }\end{array}$ \\
\hline
\end{tabular}

Kesimpulan : Mental Status Examination (MSE) tidak ada masalah gangguan jiwa, gangguan Tn. P lebih kepada Gangguan Mental

Emosional (GME/Psikososial) 


\subsection{Diagnosa Dan Terapi}

\begin{tabular}{|c|c|}
\hline DIAGNOSA KEPERAWATAN DAN TERAPI KEPERAWATAN & DIAGNOSA MEDIS \\
\hline $\begin{array}{l}\text { 1. Ansietas } \\
\text { Sp1: mendiskusikan penyebab,terjadinya prosesterjadi, tanda gejala,akibat } \\
\text { Sp2 :melatih teknik releksasi fisik } \\
\text { Sp3:melatih mengatasi ansietas dengan distraksi dan hipnotis lima0 } \\
\text { Sp4 : melatih mengatasi ansietas memalui kegiatan spritual } \\
\text { Terapi Spesialis } \\
\text { 2. Ketidakberdayaan } \\
\text { 3. Gangguan Pola Tidur }\end{array}$ & Abses Hati \\
\hline
\end{tabular}

\subsection{Implementasi Tindakan Kperawatan Dan Evaluasi}

\section{IMPLEMENTASI TINDAKAN KPERAWATAN}

Tanggal : 03 Oktober 2021

Jam : 10.00 wib

1. Menenangkan pasien

2. Memahami keadaan pasien

3. Mendiskusikan penyebab,terjadinya prosest erjadi, tanda gejala,akibat

4. Mengkaji tingkat ansietas

5. Melatih pasien teknik relaksasi fisik tarik nafas dalam

\section{EVALUASI}

S: Pasien mengatakan : ansietasnya berkurang setalah mengungkapkan perasaannya,pasien merasa tenang dan mampu mengindentifikasi situasi yang mencetus ansietas

$\mathbf{O}$ : pasien tampak tenang setelah mengungkapakan perasaan ansietasnya dan selalu melakukan tenik releksasi progesif dan terapi teknik relaksasi autogenitik

A: Ansietas pasien berkurang setalah melakukan teknik

releksasi progesif dan teknik relaksasi autognitik

$\mathbf{P}:$ intervensi dilanjutkan 


\begin{tabular}{|c|c|}
\hline IMPLEMENTASI & EVALUASI \\
\hline $\begin{array}{l}\text { Tanggal : } 03 \text { Oktober } 2021 \\
\text { Jam : } 11.00 \text { wib } \\
\text { 1. Mendiskusikan tentang penyebab dan perilaku akibat } \\
\text { ketidakberdayaan } \\
\text { 2. Bantu klien mengekspresikan perasaannya } \\
\text { 3. Bantu klien mendiskusikan masalah yang dihadapi tanpa } \\
\text { memintanya untuk menyimpulkan } \\
\text { 4. Bantu klien mengidentifikasi pemikiran yang negatif }\end{array}$ & $\begin{array}{l}\text { S : Pasien mengatakan : ketidakberdayaan nya berkurang setalah } \\
\text { mengungkapkan penyebab ketidakberdayaan dan merasa tenang } \\
\text { O : pasien tampak tenang setelah mengungkapakan perasaan } \\
\text { Ketidakberdayaan nya dan selalu melakukan teknik terapi } \\
\text { kognitif untuk melatih pikiran positif dalam dirinya (CBT) } \\
\text { A : ketidakberdayaan pasien berkurang setelah melakukan terapi } \\
\text { kognitif (CBT) } \\
\text { P : Intervensi dilanjutkan }\end{array}$ \\
\hline
\end{tabular}

\begin{tabular}{|c|c|}
\hline IMPLEMENTASI & EVALUASI \\
\hline $\begin{array}{l}\text { Tanggal : } 04 \text { Oktober } 2021 \\
\text { Jam : } 11.00 \mathrm{wib}\end{array}$ & $\begin{array}{l}\text { S : Pasien mengatakan : ansietasnya berkurang setalah melakukan } \\
\text { hipnotis } 5 \text { jari dan berdoa sesuai kepercayan }\end{array}$ \\
\hline 5. Melatih pasien mengatasi ansietas dengan ditraksi dan & $\begin{array}{l}\text { O : pasien tampak tenang setelah mengungkapakan perasaan } \\
\text { ansietasnya dan selalu melakukan tenik Hipnotis } 5 \text { Jari }\end{array}$ \\
\hline 7. Mendukung keterlibatan keluarga dengan cara yang tepat & $\begin{array}{l}\text { A : Ansietas Berkurang } \\
\mathbf{P}: \text { Intervensi Dihentikan }\end{array}$ \\
\hline
\end{tabular}




\begin{tabular}{|l|l|}
\hline \multicolumn{1}{|c|}{ IMPLEMENTASI } & \multicolumn{1}{|c|}{ EVALUASI } \\
\hline Tanggal: 04 Oktober 2021 & $\begin{array}{l}\text { S : Pasien mengatakan : perasaan ketidakberdayaan berkurang } \\
\text { setalah melakukan peningkatan pemikiran yang positif (afirmasi } \\
\text { positif) } \\
\text { Jam : 11.00 wib }\end{array}$ \\
$\begin{array}{l}\text { 5. Bantu Klien Untuk Meningkatkan Pemikiran Yang Positif } \\
\text { 6. Latih Klien Mengembangkan Harapan Positif (Afirmasi pasien tampak tenang setelah mengontrol perasaan } \\
\text { Positif) } \\
\text { 7. Latih Klien Mengontrol Perasaan Ketidakberdayaan Melalui } \\
\text { Peningkatan Kemampuan Mengendalikan Situasi Yang Masih } \\
\text { Bisa Dilakukan Pasien. } \\
\text { 8. Bantu Klien Mengidentifikasi Area-Area Situasi Kehidupan } \\
\text { Yang Dapat Dikontrolnya, Dukung Kekuatan-Kekuatan Diri } \\
\text { Yang Dapat Diidentifikasi Olehkan Klien. }\end{array}$ & P : Intervensi Dihentikan \\
\hline
\end{tabular}

\begin{tabular}{|l|l|}
\hline \multicolumn{1}{|c|}{ IMPLEMENTASI } & \multicolumn{1}{c|}{ EVALUASI } \\
\hline Tanggal : 05 Oktober 2021 & $\begin{array}{l}\text { S : Pasien mengatakan : gangguan pola tidurnya sudah berkurang } \\
\text { setelah mengenali penyebab dan akibat terjadinya gangguan pola } \\
\text { tidur }: \text { 10.00 wib }\end{array}$ \\
$\begin{array}{l}\text { 1. Mengidentifikasi tanda dan gejala, penyebab dan akibat } \\
\text { gangguan pola tidur }\end{array}$ & $\begin{array}{l}\mathbf{O}: \text { pasien sudah dapat tidur dengan baik setelah melakukan teknik } \\
\text { relaksasi otot progesif }\end{array}$ \\
2. Menjelaskan masalah gangguan pola tidur pada klien \\
3. Menjelaskan dan melatih klien mengatasi gangguan pola tidur \\
$\mathbf{A}:$ ganggun pola tidur pasien berkurang \\
$\mathbf{P}:$ intervensi dilanjutkan
\end{tabular}




\begin{tabular}{|c|l|}
\hline \multicolumn{1}{|c|}{ IMPLEMENTASI } & \multicolumn{1}{c|}{ EVALUASI } \\
\hline $\begin{array}{l}\text { Tanggal : 05 Oktober 2021 } \\
\text { Jam : 14.00 wib }\end{array}$ & $\begin{array}{l}\text { S : Pasien mengatakan : gangguan pola tidurnya berkurang setelah } \\
\text { melakukan kegiatan seperti mendengarkan musik dan melakukan } \\
\text { teknik reklaksasi } \\
\text { 4. mengidentifikasi kemampuan klien dalam upaya mengatasi } \\
\text { gangguan pola tidur }\end{array}$ \\
$\begin{array}{l}\text { 5. mendiskusikan upaya mengatasi gangguan pola tidur } \\
\text { (mendengarkan musik, mengurangi stress, membatasi tidur sudah dapat tidur dengan baik dan dapat mengatasi } \\
\text { gangguan pola tidur dengan melakukan teknik relaksasi otot } \\
\text { progresif }\end{array}$ \\
$\begin{array}{c}\text { 6. melatih klien relaksasi untuk mengatasi gangguan pola tidur } \\
\text { dan memasukan kegiatannya dalam jadwal kegiatan harian }\end{array}$ & $\mathbf{P}:$ Intervensi dihentikan \\
7. menganjurkan klien istirahat secara teratur & \\
\hline
\end{tabular}




\section{BAB 4}

\section{PEMBAHASAN}

Dari hasil asuhan keperawatan yang dilakukan pada pasien Tn. P dengan ansietas pada penyakit abses hati yang dilakukan pada Tanggal 03-05 oktober 2021 , maka penulis akan mengemukakan kesenjangan data antara teori dengan data yang didapatkan pada tinjauan kasus. Telah diuraikan juga sebelumnya mengenai tinjauan kasus baik dari segi medis maupun segi keperawatan.

Didalam memberikan asuhan keperawatan kita harus mengakui pasien sebagian makhluk social yang utuh dan unik yang terdiri dari bio, psiko, social dan spiritual, sehingga segala kemampuan kecakapan yang dimiliki oleh perawat harus dipadukan dalam mencapai tujuan yang diharapkan, karena kesembuhan dan keberhasilan implementasi keperawatan yang dilakukan tergantung dari kondisi pasien atau individu.

Berdasarkan hal itu tidak menutup kemungkinan munculnya perbedaan teori dan praktek. Penulis akan mengemukakan kesenjanagan itu melalui beberapa tahap sebagai berikut :

\subsection{Pengkajian}

Berdasarkan hasil pengkajian yang dilakukan pada Tn. P maka data yditemukan adalah Pasien merasakan Gelisah dan cemas serta susah tidur dikarenakan memikirkan keadaannya. Hasil pemerikasaan fisik di dapatkan bahwa pasien merasakan nyeri dibagian uluh hati dengan tingkat kesadaran composmentis dengan gcs : 15 (E4V5M6). Pemerikasaan tanda-tanda vital pasien didapatkan TD : 100/60 mmHg, $\mathrm{N}:$ 80x/menit, $\mathrm{P}: 20 \mathrm{x} / \mathrm{menit}, \mathrm{S}: \mathbf{3 7}, \mathbf{7}^{\mathbf{0}} \mathrm{C}, \mathrm{BB}: 59 \mathrm{~kg}, \mathrm{~TB}: 164 \mathrm{~cm}$. Saat ditanya tentang apa penyebab kecemasan tersebut, pasien mengatakan karena dia selalu memikirkan penyakitnya yang semakin parah dan takut apabila tidak dapat disembuhkan. Klien pernah mengalami riwayat penyakit yang berbeda satu tahun yang lalu yaitu hipertensi, dan pernah dirawat dibeberapa rumah sakit yang berbeda. Sementara dari riwayat kesehatan keluarga,klien tidak memiliki 
keluarga yang mengalami penyakit ini dan tidak memilki keluarga mengalami gangguan jiwa.

Kecemasan yang dialami oleh Tn.P ini di akibat kurangnya informasi mengenai pengobatan dan tidak paham akan cara menangani kecemasan yang dialaminya sehingga klien selalu gelisah dengan keadaan yang dialaminya dan selalu memikirkan tentang penyakit sehingga memperparah kondisi baik fisik serta mental dari klien itu sendiri.

\subsection{Diagnosa keperawatan}

Diagnosis keperawatan adalah bagian dari proses keperawatan yang merupakan bagian dari penilain klinis tentang pengalaman atau tanggapan individu, keluarga, atau masyarakat terhadap masalah kesehatan actual atau potensial atau proses kehidupan. Setelah dilakukannya pengkajian terhadap pasien, maka didapat diagnosa yang sesuai dengan apa yang telah dikaji sebelumnya.

Adapun diagnosa keperawatan antara lain adalah :

1. Ansietas berhubungan dengan perubahan dalam status kesehatan ditandai dengan pasien merasa cemas akan penyakitnya.

2. Gangguan pola tidur berhubungan dengan faktor eksternal ditandai dengan insomnia dan pasien tampak lemas

3. Ketidakberdayaan berhubungan dengan ketidakmampuan untuk melakukan aktifitas ditandai dengan pasien terlihat lemah

\subsection{Intervensi/Perencanaan}

Perencanaan dalam proses keperawatan lebih dikenal dengan rencana asuhan keperawatan yang merupakan tahap selanjutnya setelah pangkajian dan penentuan diagnosa keperawatan. Pada tahap perencanaan penulis hanya menyusun rencana tindakan keperawatan sesuai dengan pohon 
masalah keperawatan yaitu :Ansietas. Pada tahap ini antara tinjauan teoritis dan tinjaun kasus tidak ada kesenjangan sehingga penulis dapat melaksanakan tindakan seoptimal mungkin dan didukung dengan seringnya bimbingan dengan pembimbing.

Secara teoritis digunakan cara strategi pertemuan sesuai dengan diagnosa keperawatan yang muncul saat pengkajian. Adapun upaya yang dilakukan penulis yaitu :

1. Pasien menunjukan eskpresi sedih dan selalu memikirkan keadaannya

2. Klien tidak dapat mengontrol dengan baik perasaan nya ketika penyakitnya kambuh, dan selalu khawatir dengan keadaannya saat ini

3. Klien mengalami ketergantungan pada orang lain yang dapat mengakibatkan ititabilitas, ketidaksukaan, marah dan rasa bersalah Klien menunjukan ekspresi ketidakpuasan terhadap ketidakmampuan melakukanaktivitas atau tugas sebelumnya. Klien menunjukan ekspresi keraguan tantang performa peran.

\subsection{Implementasi}

Pada tahap implementasi, penulis hanya mengatasi 1 masalah keperawatan yakni: diagnosa keperawatan Ansietas merupakan keadaan emosi dan pengalaman subyektif induvidu,tanpa objek spesifik karena ketidaktahuan dan mendahului semua pengalaman yang di alami penyakit Abses Hati.

\subsection{Evaluasi}

Pada tinjauan teoritis evaluasi yang diharapkan adalah :

a. Membina hubungan saling percaya

b. Mengenali dan mengekspresikan emosinya

c. Mampu mengenal ansietas

d. Mampu mengatasi ansietas melalui teknik releksasi progesif

e. Mampu mengatasi ansietas dengan terapi relaksasi autogenitik 


\section{BAB 5}

\section{PENUTUP}

\subsection{Kesimpulan}

Berdasarkan uraian pada pembahasan diatas, maka penulis dapat disimpulkan bahwa:

1. Saat memberikan asuhan keperawatan pada pasien dengan kecemasan, akan ditemukan adanya perilaku kecemasan dan cara berkomunikasi yang kurang jelas akibat pasien gugup. Sehingga diperlukan kesabaran dalam berkomunikasi dengan pasien. Dan juga bina hubungan saling percaya sehingga menciptakan suasana yang terapeutik dalam melaksanakan asuhan keperawatan.

2. Diagnosa keperawatan yang utama pada klien dengan Kecemasan : Abses Hati

3. Perencanaan dan implementasi keperawatan disesuaikan dengan strategi pertemuan pada pasien.

4. Evaluasi keperawatan yang dilakukan menggunakan metode subyektif,obyektif,assessment dan planing.

5. Dalam melaksanakan asuhan keperawatan pada pasien, khususnya dengan kecemasan dibutuhkan kehadiran keluarga disisinya untuk menemani dan menguatkan pasien. Disamping itu juga dibutuhkan kehadiran keluarga untuk memberikan data dan membina kerjasama dalam memberi asuhan keperawatan pada pasien.

\subsection{Saran}

\section{Untuk institusi pendidikan}

Diharapkan lebih meningkatkan pelayanan pendidikan yang lebih tinggi dan menghasilkan tenaga kesehatan yang profesional berwawasan global

\section{Untuk keluarga}

Diharapkan hendak selalu bergantian untuk menjaga pasien yang berada di rumah sakit, agar pasien merasa selalu diperhatikan dan lebih tenang dalam menjalani proses keperawatan. 


\section{DAFTAR PUSTAKA}

1. Ada, A. D. (2018). Standards Of Medical Care In Diabetes 2017. (Hal. 41). Usa: Ada

2. .Aru, W. Sudoyo,(2017). Buku Ajar Ilmu Penyakit Dalam, Jilid 1 Edisi Empat.Jakarta : Balai Penerbitan Fk-Ui.

3. Bulechek, G. M . 2018 Nursing Interventions Classification (Terjemahan). Indonesia : Elsevier Inc

4. Cameeron.(2015). Prinsip-Prinsip Penyakit Dalam. Jakarta: Binarupa Aksara.

5. Ernawati, D . 2016 .Asuhan Keperawatan Jiwa Dengan Masalah Psikososial. Jakarta: Trans Info Media

6. Hulu, E. K., \& Pardede, J. A. (2016). Dukungan Keluarga Dengan Tingkat Kecemasan Pasien Pre Operatif Di Rumah Sakit Sari Mutiara Medan. Jurnal Keperawatan, 2(1), 12.

7. Pardede, J. A. (2020). Konsep Ketidakberdayaan.

8. Kusumawati \& Hartono. 2019. Buku Ajar Keperawatan Jiwa. Malang : Salemba Medika Moorhead, S. 2016. Nursing Outcomes Classification (Terjemahan). Indonesia : Elsevier Inc

9. Mansjoer, Arief.(2016). Kapita Selekta Kedokteran; Jilid 1, Edisi Ketiga.Jakarta : Media Aesculapius. Halaman 512.

10. Microsoft Encantta Reference Library.( 2017 ). Liver, Amebiasis Abses And Calf Diphteria/ Fusa Bakteriun Necrosphorum.

11. Pardede, J. A., Hulu, D. E. S. P., \& Sirait, A. (2021). Tingkat Kecemasan Menurun Setelah Diberikan Terapi Hipnotis Lima Jari pada Pasien Preoperatif. Jurnal Keperawatan, 13(1), 265-272.

12. Pardede, J. A., \& Tarigan, I. (2020). The Anxiety Level of Mother Presectio Caesar with Benson's Relaxation Therapy. Jendela Nursing Journal (Jnj), 4(1), 20-28.https://doi.org/10.31983/jnj.v4i1.5801

13. Pardede, J. A., \& Simangunsong, M. M. (2020). Family Support With The Level of Preschool Children Anxiety in the Intravenous Installation. Jurnal Keperawatan Jiwa (JKJ): Persatuan Perawat Nasional Indonesia, 8(3), 223-234.

14. Riyadi \& Purwanto. 2019. Asuhan Keperawatan Jiwa. Yogyakarta : Graha 
Ilmu

15. Stuart. Gail. W, Keliat. Budi. Anna,\& Pasaribu. Jesika.(2016). Keperawatan Kesehal11tan Jiwa: Indonesia : Elsever.

16. Pardede, J. A., Simanjuntak, G. V., \& Waruwu, J. F. A. P. (2020). Penurunan Tingkat Kecemasan Pasien HIV/AIDS melalui Terapi Hipnotis Lima Jari. Coping: Community of Publishing in Nursing, 8, 85-90.

17. Sulastri, S., Trilianto, A. E., \& Ermaneti, Y. (2019). Pengaruh Komunikasi Terapeutik Perawat terhadap Tingkat Kecemasan pada Pasien Pre Operasi. Jurnal Keperawatan Profesional, 7(1). https://doi.org/10.33650/jkp.v7i1.503

18. Wahyuningsih, A. S., Saputro, H., \& Kurniawan, P. (2021). Analisis Faktor Kecemasan terhadap Tingkat Kecemasan Pasien Pre Operasi Hernia di Rumah Sakit. Jurnal Keperawatan Jiwa (JKJ): Persatuan Perawat Nasional Indonesia, 9(3), 613-620.

19. Sumoked, A., Wowiling, F., \& Rompas, S. (2019). Hubungan Mekanisme Koping Dengan Kecemasan Pada Mahasiswa Semester Iii Program Studi Ilmu Keperawatan Fakultas Kedokteran Yang Akan Mengikuti Praktek Klinik Keperawatan. Jurnal Keperawatan, 7(1).

20. Pardede, J. A., Keliat, B. A., Damanik, R. K., \& Gulo, A. R. B. (2020). Optimalization of Coping Nurses to Overcoming Anxiety in the Pandemic of Covid-19 in Era New Normal. Jurnal Peduli Masyarakat, 2(3), 105112.http://dx.doi.org/10.31000/jkft.v4i2.2504

21. Cory'ah, F. A. N., \& Wahyuni, I. G. A. P. S. (2019). Hubungan Sindrom Menopause Dengan Tingkat Kecemasan Ibu Menopause Diwilayah Kerja Puskesmas Ubung Kabupaten Lombok Tengah Tahun 2018. Jurnal Kebidanan Akademi Kebidanan Jember, 3(1), 8-16.

22. Hayat, A. (2017). Kecemasan dan metode pengendaliannya. Khazanah: Jurnal Studi Islam Dan Humaniora, 12(1).

23. Pardede, J., Simanjuntak, G. V., \& Manalu, N. (2020). Effectiveness of deep breath relaxation and lavender aromatherapy against preoperative patient anxiety. Diversity and Equality in Health and Care, 17(4), 168-173. doi: 10.36648/206 9-5471.17.4.209 